ISSN 1412-2936

EISSN 2549-7308

\title{
PENGARUH CUSTOMER RELATIONSHIP MANAGEMENT (CRM) TERHADAP LOYALITAS PELANGGAN XL AXIATA SAMPANG
}

\author{
WAHYU MAULANA \\ DEVI LESTARI PRAMITA PUTRI
}

\section{UNIVERSITAS MADURA}

\begin{abstract}
ABSTRAK
Pelanggan merupakan salah satu faktor penentu sebuah perusahaan untuk terus survive dalam persaingan bisnis. Hal ini dilakukan agar pelanggan menjadi loyal terhadap sebuah perusahaan. Tingkat loyalitas ini dapat tercapai dengan adanya Customer Relationship Mangement (CRM) yang tepat sasaran sehingga tercipta hubungan yang baik dan saling menguntungkan dengan para pelanggannya. Tujuan penelitian ini adalah untuk menguji pengaruh CRM terhadap loyalitas pelanggan XL Axiata Sampang. Dasar penelitian ini menggunakan pendekatan kuantitatif deskriptif. Teknik yang digunakan dalam pengumpulan data dengan studi pendahuluan, wawancara dan kuesioner serta studi kepustakaan. Subjek penelitian ini adalah penduduk yang berdomisili Sampang tepatnya di kelurahan Banyuanyar. Penelitian ini mengambil sampel dengan teknik isidental dan terdapat 40 responden yang peneliti temui setelah menyediakan 60 lembar angket. Hasil penelitian ini menunjukkan bahwa CRM berpengaruh secara positif dan signifikan terhadap loyalitas pelanggan $\mathrm{XL}$ Axiata Sampang. Hasil ini dapat dilihat pada analisis regresi sederhana dimana hasil dari perhitungannya adalah $Y=1,043+$ 0,687 X. Dan nilai R sebesar $47,4 \%$ sedangkan nilai $R$ square $22,5 \%$. Data yang diperoleh selanjutnya juga dihitung menggunakan teknik presentasi dengan perhitungan SPSS 16 for windows. Hasil penelitian ini menunjukkan bahwa ada pengaruh CRM terhadap Loyalitas pelanggan XL Axiata Sampang dengan hasil t-hitung sebesar 3,322
\end{abstract}

Kata kunci : Customer Relationship Management (CRM) dan Loyalitas pelanggan

\section{PENDAHULUAN \\ LATAR BELAKANG}

Dunia globalisasi saat ini menuntut setiap perusahaan dan usaha untuk memberikan yang terbaik kepada pelanggannya, hal ini disebabkan setiap usaha dan perusahaan ingin memenangkan hati mereka. Kita telah melihat berbagai perusahaan berdiri disetiap sudut jalan, dan membuat mereka harus bersaing ketat dengan kompetitornya, bahkan untuk memiliki pelanggan pesaing menjadi suatu keharusan yang tidak bisa ditolak oleh setiap usaha juga perusahaan. Bisa kita bayangkan Jika perusahaan tadi gagal dalam mempertahankan pelanggannya dan memilih untuk pindah hati, tidak diragukan lagi perusahaan tersebut hanya menunggu waktu untuk gulung tikar alias bangkrut. Untuk itu suatu 
ISSN 1412-2936

EISSN 2549-7308

perusahaan harus menganalisis apa yang terjadi dan bagaimana mereka kehilangan pelanggannya. Jika pelanggan lama yang selalu membeli produk perusahaan saja sudah pergi dari perusahaan akan lebih sulit lagi untuk mempertahankan pelanggan yang masih baru untuk menjadi pembeli yang secara rutin di suatu perusahaan.

Berbicara akan pelanggan, mendatangkan pelanggan baru memerlukan biaya yang tinggi dari pada mempertahankan pelanggan lama Dari pada perusahaan menyeluarkan banyak biaya untuk mendatangkan pelanggan baru yang belum tentu diketahui kesetiaannya, mengapa mereka tidak mempertahankan pelanggan lama setia mereka, Selain biaya yang rendah, kesetiaan dalam pembelian ulangpun hanya memerlukan biaya yang lebih rendah. Biaya yang dimaksud adalah bagaimana perusahaan memfokuskan dalam mengikat emosional pelanggan mereka untuk selalu loyal kepadanya. Salah satu strategi yang efektif dalam menjalin hubungan pelanggan dalam jangka panjang untuk menjaga loyalitas pelanggan adalah dengan strategi CRM (Customer Relationship Mangement). Menurut Buttle (2007), CRM adalah strategi inti dalam bisnis yang mengintegrasikan proses-proses dan fungsi-fungsi internal dengan semua jaringan eksternal untuk menciptakan serta mewujudkan nilai bagi para konsumen sasaran secara profitabel. CRM didukung oleh data konsumen yang berkualitas dan teknologi informasi. Sehingga CRM adalah bagaimana perusahaan menumbuhkan nilai mereka pada pelanggan. CRM jika dilihat dari sejarahnya adalah turunan dari RM (relationship management) yang membahas tentang managemen hubungan, sehingga baik hubungan bisnis yang saling menguntungkan RM juga bisa hubungan dengan yang lainnya seperti pelanggan dan lainnya, sehingga dari berbagai hubungan muncullah CRM untuk menjaga hubungan dengan pelanggan. Dengan strategi ini, pelanggan diikat agar mereka tidak seliweran untuk melirik perusahaan lain, meski terkadang mereka menoleh namun dihati mereka tetap bersama perusahaan, tujuan dari setiap strategi CRM adalah untuk mengembangkan hubungan yang menguntungkan dengan pelanggan (Butlle, 2007) dari pernyataan ini bisa dilihat adanya hubungan yang menguntungkan antara perusahaan dan pelanggan jika terjadi secara berkesinambungan, dalam artian menguntungkan perusahaan yaitu tercapai target profit mereka. Tentu saja pelanggan adalah satu-satunya sumber yang dapat mendatangkan laba, lebih kasarnya lagi mereka adalah (sapi perah yang bisa diperas uangnya).

Menurut Butlle (2007), CRM dikaji menjadi tiga tataran diantaranya : strategis, operasional dan analitis, yang mana strategis sendiri terfokus pada upaya mengembangkan kultur usaha yang berorientasi pada pelanggan, dan operasional terfokus pada cara-cara berhubungan dengan pelanggan dan analistis digunakan untuk mengekspoitasi data konsumen untuk meningkatkan nilai mereka. Dari hal di atas perusahaan atau usaha mampu mengetahui, memahami dan berusaha memenuhi kebutuhan dan keinginan pelanggan agar pelanggan merasa terpuaskan dan ahirnya mendatangkan keloyalitasan mereka.

Begitupun dengan perusahaan besar XL 
ISSN $1412-2936$

EISSN 2549-7308

Axiata, perusahaan yang berkerja pada bidang komunikasi, mereka juga menggunakan CRM agar tetap melakukan hubungan yang berkesinambungan dengan pelanggan dan dimana mereka juga menambah nilai-nilai mereka dengan integritas, kerja sama tim dan kesempurnaah layanan, salah satunya kesempurnaan layanan tadi adalah XL Center atau untuk Customer Service.

Beralih kepada loyalitas, Menurut Griffin (2003), kepuasan saja belum mendatangnya keloyalitasan pelanggan. Teori ini menyatakan Harvard Business Review melaporakan "65-85\% dari para pelanggan memilih pemasok baru yang mengatakan bahwa mereka puas atau sangat puas dengan pemasok lama" dan juga forum corporation melaporkan "sekitar $40 \%$ dari para pelanggan dalam studinya yang menyatakan puas ternyata pindah pemasok tanpa ragu-ragu" dari pernyataan di atas bisa kita lihat bahwa kepuasan tidak selalu mendatangkan loyalitas, namun perlu digaris bawahi juga bahwa sebelum orang loyal mereka harus merasakan kepuasan. Dan dari ini penulis mencoba menyambungkan dengan CRM XL untuk memelihara hubungan yang berguna untuk jangka panjannya, Karena pada ahirnya CRM akan mendatangkan loyalitas dari pelanggan yang akan menguntungkan perusahaan melalui perantara kepuasan.

Di sini penulis melihat meski XL Axiata menerapkan strategi CRM yang baik dan menurut mereka bagus, belum tentu pelanggan merasa terpuaskan apalagi loyal dengan CRM yang mereka terapkan, Salah satu contoh kejengkelan yang penulis temui di lapangan dari segi operasional yaitu sistem yang terotomatisasi yang menjadi salah satu CRM dengan artian setiap ada informasi akan produk atau hal-hal yang berhubungan dengan hal yang baru sistem tadi akan secara otomatis memberitahukannya kepada pelanggan, namun sayangnya informasi yang terlalu berlebihan membuat pelanggan merasa terganggu bahkan tidak membacanya, hal ini terlihat dari kenyataan bahwa ada beberapa keluarga, teman, tetangga, relasi dan yang lainnya bercerita tentang ketidak nyamanan karna terlalu sering mendapat sms dari XL Axiata, apalagi saat ini banyak RBT yang menambah datangnya SMS kepada pelanggan. Namun penulis masih bertanya-tanya karena meski mereka merasa terganggu dengan SMS tersebut, mereka tetap menggunakan kartu XL Axiata ini, bahkan dalam jangka waktu yang lama, maka muncul apakah CRM yang digunakan XL masih bermakna. Dan ahinrya muncullah judul penelitian PENGARUH CUSTOMER RELATIONSHIP MANAGEMENT (CRM) TERHADAP LOYALITAS PELANGGAN XL AXIATA SAMPANG

\section{RUMUSAN MASALAH}

Berdasarkan latar belakang dari diatas peneliti merumuskan masalah yakni : Bagaimana pengaruh CRM (Customer Relationship Management) terhadap tingkat loyalitas pelanggan XL Axiata Sampang

\section{TUJUAN PENELITIAN}

Adapun tujuan dari penelitian ini adalah Ingin mengetahui pengaruh CRM (Customer Relationship Management) terhadap tingkat loyalitas pelanggan XL 
ISSN 1412-2936

EISSN 2549-7308

Axiata Sampang.

\section{KAJIAN PUSTAKA CUSTOMER MANAGEMENT (CRM) \\ RELATIONSHIP}

Lingkungan bisnis selalu berubah dan bergerak dinamis dari masa ke masa, sehingga semua pelaku bisnis harus merencakan strategi-strategi tertentu untuk memenangkan persaingan dan unggul dari pesaing lainnya. Salah satu strateginya adalah dengan menerapkan CRM. Menurut Buttle (2007), CRM adalah strategi inti dalam bisnis yang mengintegrasikan proses-proses dan fungsi-fungsi internal dengan semua jaringan eksternal untuk menciptakan serta mewujudkan nilai bagi para konsumen sasaran secara profitabel. CRM didukung oleh data konsumen yang berkualitas dan teknologi informasi. Bisa dikatakan bahwa CRM ini bisa berjalan dengan adanya dukungan dari data konsumen yang berkualitas sehingga akan diproses agar CRM bisa lebih baik, karena konsumen yang menjadi sasarannya adalah konsumen yang profitabel alias yang bisa mendatangkan profit bagi perusahaan, apapun istilahnya CRM adalah praktik berbisnis yang terfokus atau berorientasi pada pelanggan (Buttle, 2007). Jadi bisa dilihat disini bahwa CRM ini nantinya adalah proses untuk menciptakan pelanggan yang loyal dan CRM ini nantinya akan terfokus dan berorientasi kepada pelanggan, sehingga perusahaan atau usaha akan memusatkan dan memikirkan caranya agar pelanggan tetap berhubungan baik dengan perusahaan agar terciptanya hubungan emosional dengan usaha atau perusahaan.
Menurut Kotler dan Amstrong (2006), CRM adalah keseluruhan proses membangun dan memelihara hubungan pelanggan yang menguntungkan dengan menghantarkan nilai dan kepuasan pelanggan yang unggul. Proses ini berhubungan dengan semua aspek untuk meraih, mempertahankan, dan menumbuhkan pelanggan. Bisa dilihat bahwa CRM ini adalah hubungan yang menguntungkan bagi perusahaan atau usaha yang mana dengan adanya hubungan emosional yang baik, pelanggan melakukan pembelian di perusahaan secara continually, yang mana juga CRM akan selalu berhubungan dengan proses yang berhubungan dengan beberapa aspek diantaranya untuk meraih pelanggan baru bisa jadi dikarenakan anjuran rekan dan tetangga selanjutnya mempertahankan pelanggan agar tidak pindah hati dan tergoda dengan produk yang ditawarkan perusahaan pesaing yang sejenis dan yang terahir adalah menumbuhkan pelanggan untuk selalu meningkat.

Menurut Heide (1994) dan Reinarts \& Kumar (2003) dalam Body and Limayem (2006), "CRM is refers to all business activities directed towards intiating, establishing, maintraining, adan develophing successful long term relational exchanges" yang mana mengacu pada semua kegiatan usaha yang diarahkan untuk memulai, membangun, memelihara dan mengembangkan/ menumbuhkan pertukaran hubungan dalam jangka panjang yang sukses. Sehingga CRM ini akan menjadikan pertukaran hubungan yang sukses dalam jangka panjang dengan memulainya dari sebuah hubungan yang membangun pelanggan 
ISSN $1412-2936$

EISSN 2549-7308

memelihara pelanggan dan menumbuhkan palanggan.

Dari ketiga definisi di atas peneliti bisa mengambil kesimpulan bahwa CRM ini adalah strategi dalam menciptakan hubungan yang menguntungkan bagi perusahaan atau usaha dalam jangka panjang dengan cara membangun, memelihara dan menumbuhkan hubungan yang bersifat emosional dengan pelanggan, Karena jika perusahaan atau usaha sudah mengikat emosional pelanggan mereka, pelanggan akan menjadi pelanggan yang loyal yang akan memebeli secara continually.

Tujuan CRM secara umum dikatakan bahwa strategi CRM adalah untuk mengembangkan hubungan yang menguntungkan dengan pelanggan (Butlle, 2007). Salah satunya dengan menjual produk dan jasa tambahan kepada pelanggan. Tujuan inti dari CRM adalah profitabilitas pelanggan. Untuk tujuan ini juga hampir sama dengan salah satu definisi dari CRM yaitu mencari profitabilitas pelanggan sehingga utuk bisa mencari profitabilitas organisasi yang terdapat pada perusahaan atau usaha harus bisa melacak berapa pendapatan dan biaya yang dikenakan kepada pelanggan.

Menurut Butlle (2007), CRM dari tiga tataran diantaranya tataran strategis, operasional dan analitis

a. Tataran strategis

CRM strategis ini merupakan upaya perusahaan atau usaha untuk mengembangkan kultur usaha yang berorientasi pada pelanggan. Sehingga karyawan berkerja di perusahaan harus mempunyai kultur untuk memprioritaskan pelanggan mereka dengan selalu menanamkan di benak karyawan bahwa pelanggan memiliki arti yang penting bagi perusahaan. Kultur tadiadalah cara untuk merebut hati konsumen dan menjaga loyalitas mereka dengan menciptakan serta memberikan nilai bagi pelanggan, sehingga dari hal tadi perusahaan atau usaha dapat mengungguli perusahaan atau usaha pesaing dalam mengambil hati konsumen. Kultur harus diawali dengan contoh dari sang pemimpin perusahaan yang kemudia akan diikuti oleh para bawahan karena telah di teladani oleh sang pemimpin seperti kata pepatah guru kencing berdiri, murit kencing berlari. Semua langkah yang dilakukan adalah untuk dapat meningkatkan nilai perusahaan di mata pelanggan, sehingga karyawan termotivasi yang pada ahirnya akan bermuara pada kepuasan pelanggan dan sebagainya.

b. Tataran operasional

Untuk tataran operasional ini lebih terfokus pada otomatisasi cara-cara perusahaan dalam berhubungan dengan para pelanggan. Untuk otomatisasi ini menggunakan aplikasi perangkat lunak sehingga CRM memungkinkan untuk melakukan fungsi-fungsi pemasaran, penjualan dan pelayanan berjalan secara otomatis, karena telah didukung oleh aplikasi perangkat lunak. Salah satu contoh dari otomatis pemasaran ini adalah dengan mempermudah dalam memberikan penawaran kepada pelanggan. Sedangkan untuk penjualan bisa dengan mengirimkan produk terbaru melalui via email dan lain sebagainya. Menurut Kotler dan Amstrong (2006), perusahaan perlu berfikir secara mendalam tentang masalah perecanaan armada penjualan, penjualan melalui armada otomatiasi juga harus diperhitungkan dalam perencanaannya apalagi dalam keefektifannya dalam 
ISSN 1412-2936

EISSN 2549-7308

penjualan, sendangkan yang terahir adalah fungsi pelayanan, contoh fungsi pelayanan ini adalah dengan memberikan call center dalam menanyakan keluhan pelanggan dana solusi yang diberikan.

c. Tataran analitis

Tataran analisis digunakan untuk mengesploitasi data konsumen demi meningkatkan nilai mereka pada perusahaan. Untuk tataran analisis ini CRM mengunakan sistem yang dikembangkan berdasarkan informasi mengenai konsumen, salah satunya dengan menggunakan alat penggalian data sehingga perusahaan dapat mengintograsi data tersebut. CRM analitis sendiri sudah menjadi bagian penting dalam penerapan CRM yang efektif, dan nilai pelangganpun dapat digunakan membuat berbagai keputusan CRM, misalnya konsumen mana yang akan dibidik, konsumen mana yang harus diprioritaskan. Bahkan CRM analitis sendiri dapat memberikan solusi yang tepat waktu, dan juga yang bersifat personal bagi segala permasalah konsumen, sehingga terpecahnya dengan cepat masalah tadi, konsumen akan semakin puas dengan perusahaan atau usaha

\section{LOYALITAS PELANGGAN}

Menurut Body and Limayem (2006) "The development of loyalty involves building and sustaining a relationship with a customer, which leads tothe repeated purchase of products or services over a given period of time" yang artinya perkembangan dari loyalitas meliputi membangun dan memelihara hubungan dengan pelanggan yang mengarahkan pada pembelian ulang produk dan jasa pada waktu tertentu. Loyalitas pelanggan bisa dalam artian mereka melakukan pembelian secara berulang dan rutin dalam jangka waktu tertentu.

Terdapat 4 jenis loyalitas yang berbeda muncul bila keterikatan rendah dan tinggi diklarifikasi silang dengan pembelian ulang yang rendah dan tinggi, menurut Griffin (2003), 4 jenis tersebut yaitu :

1. Tanpa loyalitas.

Beberapa pelanggan tidak mengembangkan loyalitas terhadap produk/ jasa tertentu. Maka dari itu secara umum suatu perusahaan harus menghindari untuk membidik pembeli jenis ini karena mereka tidak akan perah menjadi pelanggan yang loyal

2. Loyalitas yang lemah

Keterikatan yang rendah digabung dengan pembelian berulang yang tinggi menghasilkan loyalitas yang lemah. Pelanggan yang seperti ini adalah membeli dengan faktor kebiasan saja. Dengan alasan bahwa mereka sering menggunakan produk ini dan bukan datang dari loyalitas. Pembeli yang seperti ini bisa diubah dari loyalitas lemah ke dalam bentuk loyalitas yang lebih tinggi dengan mendekati mereka secara aktif dan meningkatkan referensi positif di benak mereka untuk mengenai produk anda dari pada pesaing.

3. Loyalitas tersembunyi

Tingkat referensi yang lebih tinggi digabung dengan tingkat pembelian berulang yang rendah menunjukkan loyalitas tersembunyi. Bila pelanggan memiliki loyalitas yang tesembunyi, pengaruh situasi dan bukan pangaruh sikap yang menentukan pembelian berulang

4. Loyalitas premium

Jenis loyalitas ini tinggi dan tingkat pembelian berulang yang juga tinggi, ini 
ISSN $1412-2936$

EISSN 2549-7308

adalah yang paling dapat ditingkatkan, terjadi bila ada tingaktan keterikatan yang tinggi dan tingkat pembelian berulang yang juga tinggi. Ini adalah jenis pelanggan yang sangat disukai disetiap perusahaan dan usaha, hal ini sangat jelas karena tingkat pembelian ulang yang teratur. Untuk tingkatan ini para pelanggan merupakan penganjur kepada keluarga atau rekan kerja dan juga masih banyak yang lainnya untuk mencoba pilihan mereka, pelanggani ini juga bisa disebut pelanggan vokal, alias yang selalu menyarankan kepada orang lain untuk membelinya.

Tingkatan loyalitas pelanggan menurut Griffin (2003) sebagai berikut :

- Tahap satu : suspect. Suspect (tersangka) adalah orang yang mungkin membeli produk atau jasa anda. Kita menyebutknya tersangka karena kita percaya atau menyangka mereka akan membeli.

- Tahap dua : prospek. Prospek adalah orang yang membutuhkan produk atau jasa anda dan memiliki kemampuan membeli. Meskipun prospek belum membeli dari anda, ia mungkin telah mendengar tentang anda, membaca tentang anda, atau seseorang yang merekomendasikan anda kepadanya. Prospek mungkin tahu siapa anda, di mana anda, dan apa yang anda jual, tetapi mereka masih belum membeli dari anda.

- Tahap tiga : prospek yang diskualifikasi. Prospek yang diskualifikasi adalah prospek yang telah cukup anda pelajari untuk mengetahui bahwa mereka tidak membutuhkan, atau tidak memiliki kemampuan membeli produk anda.

- Tahap empat : pelanggan pertama kali. Pelanggan pertama kali adalah orang yang telah membeli dari anda satu kali. Orang tersebut bisa merupakan pelanggan anda dan sekaligus merupakan pelanggan pesaing anda

- Tahap lima : pelanggan berulang. Pelanggan berulang adalah orang-orang yang telah membeli dari anda dua kali atau lebih. Mereka mungkin telah membeli produk yang sama dua kali atau membeli dua produk atau jasa yang berbeda pada dua kesempatan atau lebih.

- Tahap enam : klien. Klien membeli apapun yang anda jual dan dapat ia gunakan. Orang ini membeli secara teratur. Anda memiliki hubungan yang kuat dan berkelanjutan, yang menjadikan kebal terhadap tarikan pesaing.

- Tahap tujuh : penganjur. Penganjur (advocad) seperti klien, pendukung membeli apapun yang anda jual dan dapat ia gunakan serta membelinya secara teratur. Tetapi, penganjur juga mendorong orang lain untuk membeli dari anda. la membicarakan anda, melakukan pemasaran bagi anda dan membawa pelanggan kepada anda.

Menurut Butlle (2007), ini disebut tangga nilai dalam upaya menempatkan kesetian konsumen dalam berbisnis dintara juga ada 7 anak tangga diantaranya :

1. Suspect, apakah konsumen itu cocok dengan profil target market?

2. Prospect, konsumen sesuai dengan profil yang dimaksud dan pihak perusahaan melakukan langkah pendekatan awal.

3. Konsumen perdana, konsumen yang melakukan pembelian pertama kali.

4. Konsumen ulang, konsumen yang melakukan pemebelian tambahan.

5. Konsumen mayoritas, konsumen 
ISSN 1412-2936

EISSN 2549-7308

memilih perusahaan sebagai supplier pilihan mereka.

6. Konsumen setia, konsumen yang tak berpindah ke supplier lain dan menunjukkan sika amat positif kepada perusahaan.

7. Pendukung, konsumen yang mendatangkan pemasukan tambahan berkat referensi lisan mereka yang mendatangkan konsumen konsumen baru.

Demikianlah tingkatan loyalitas konsumen meski menurut Dwyer dalam Bullte (2007) "tidak semua konsumen menempuh jalur yang sama dari status sebagai suspect sampai ke pendukung alias konsumen setia". Jadi kadang ada konsumen yang bertahan sampai fase teratas namun disisi lain juga ada yang hanya di fase tengah tidak berpindah ke atas bahkan hanya menjadi konsumen perdana alias pembeli pertama kali dan tidak membeli untuk pembelia selanjutnya atau berulang. Namun buku itu menjelaskan dengan adanya CRM maka akan di analisis sampai dimana pelanggan mereka mencapai tingkatan loyalitas tadi sehingga bisa meningkatkan tingkatannya dengan menggunakan strategi CRM.

\section{PENELITIAN TERDAHULU}

Berikut beberapa penelitian terdahulu dalam penelitian ini yang digunakan oleh peneliti sebagai bahan kajian, yaitu :

1. Rinny E. Kalalo (2013) "CRM dan Kualitas Pelayanan Pengaruhnya Terhadap Loyalitas Konsumen PT. Matahari Dept. Store Manado". Jumlah populasi sebanyak 234 sedangkan sampel sebanyak 71 responden. Berdasarakan hasil analisis penelitian ini menunjukkan bahwa secara parsial dan simultan kedua variabel ini berpengaruh positif signifikan terhadap loyalitas konsumen

2. Satriyo UP Bhaskara dkk (2014) "CRM dan Personal Selling Pengaruhnya Terhadap Kepuasan Konsumen Pada PT. Virgo Ekspres Tours \& Travel Manado". Jumlah populasi sebanyak 1239 dan sampel sebanyak 100 responden. Berdasarakan hasil analisis penelitian ini menunjukkan bahwa secara parsial dan simultan kedua variabel ini berpengaruh positif signifikan terhadap kepuasan konsumen

3. Hesti Kartika Sari (2009) "Efektivitas Loyality Program dalam CRM Terhadap Kepuasan dan Loyalitas Pelanggan (Studi Program Im3@school Community pada PT. Indosat, Tbk Cabang Malang)". Hasil penelitian menunjukkan adanya pengaruh signifikan antara CRM melalui loyality program terhadap kepuasan dan loyalitas pelanggan, adanya pengaruh yang signifikan antara kepuasan pelanggan terhadap loyalitas pelanggan serta untuk menghasilkan pelanggan yang loyal dengan memberikan nilai loyality program yang tinggi dan kuncinya adalah kepuasan

\section{KERANGKA BERPIKIR}

Terdapat kerangka berpikir penelitian

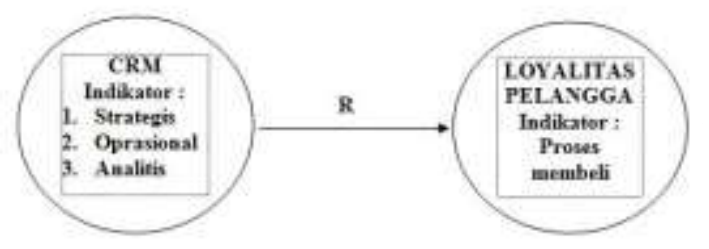


ISSN $1412-2936$

EISSN 2549-7308

\section{HIPOTESA}

Adapun hipotesis penelitian ini adalah terdapat pengaruh yang signifikan antara CRM terhadap tingkat loyalitas pelanggan XL Axiata Sampang.

\section{METODOLOGI PENELITIAN JENIS PENELITIAN}

Jenis penelitian ini adalah penelitian deskriptif. Menurut Narbuko dan Achmadi (2013), penelitian deskriptif yaitu penelitian yang berusaha untuk menuturkan pemecahan masalah yang ada sekarang berdasarkan data-data, jadi ia juga menyajikan data, menganalisi dan menginterprestasi. Sehingga penelitian ini ahirnya akan memecahkan masalah yang ada sesuai dengan data-data yang telah diproses dimulai dari meyajikan data, menganalisa data yang telah diperoleh dan kemudian menginterprestasikannya. Pemecahan masalah nantinya akan mencari hubungan satu variabel yang satu dengan variabel yang lain, variabel independen dengan simbol $X$ dan dependen dengan simbol Y. Variabel inilah yan nantinya akan dicari hubungan atau pengaruhnya melalui uji hipotesis.

\section{OBJEK PENELITIAN}

Lokasi penelitian yang diambil oleh peneliti yakni terletak di Kelurahan Banyuanyar Sampang. Lokasi ini dipilih karena fokus utama penelitian adalah pelanggan yang menggunakan XL Axiata di lokasi tersebut.

\section{TEKNIK PENGUMPULAN DATA}

Teknik pengumpulan data dalam penelitian ini sebagai berikut :

1. Studi pendahuluan merupakan salah satu kegiatan persiapan yang dilakukan oleh peneliti dengan tujuan untuk menentukan objek (variabel) dan subjek (responden) penelitian yang tepat, sesuai dengan tema penelitian yang menjadi fokus kajian peneliti.

2. Studi lapangan

- Wawancara. Wawancara yang dipakai dalam penelitian ini adalah wawancara yang tidak terstuktur. Menurut Arikunto (2010), wawancara ini adalah pedoman yang hanya memuat garis besar yang akan ditanyakan. Dan Wawancara juga merupakan sebuah proses memperoleh keterangan untuk tujuan penelitian dengan cara tanya jawab sambil bertatap muka antara pewawancara dengan responden atau orang yang diwawancarai dengan atau dengan menggunakan pedoman wawancara (Bungin, 2006). sehingga bisa dikatakan si pewawancara adalah pengemudi untuk jawaban dari responden.

- Kuesioner. Menurut Sugiyono (2010), kuisioner/ angket merupakan teknik pengumpulan data yang dilakukan dengan cara memberi seperangkat pertanyaan atau penyataan yang tertulis kepada responden untuk di jawab sehingga peneliti lebih efisien dalam mengumpulkan data karena tau apa yang bidang diharapkan responden dengan memberikan pertanyaan tadi. Merumuskan pertanyaan itu penting dalam polling, yakni membuat pertnyaan yang tepat yang dapat di persepsi sama oleh semua responden (Noor, 2011) 
ISSN $1412-2936$

EISSN 2549-7308

sehingga kata-katanya harus jelas.

3. Studi kepustakaan. Menurut Tika (2006) studi kepustakaan merupakan metode pengumpulan data sekunder. Untuk datanya seorang peneliti langsung mencatatnya ke dalam tulisan atau diolah kembali dengan menyebutkan sumber perolehan data. Dengan studi pustaka ini peneliti akan mengolah sumber perolehan data yang akan memperkuat penelitian ini.

\section{TEKNIK ANALISA DATA}

Pada peneltian ini tehnik analisa data menggunakan analisa kualitatif dan analisa kuantitatif, diantaranya : a. Analisa kualitatif. Untuk analisis ini dengan menggunakan skala likert. Menurut Azwar (2011), skala likert berisi tentang pertanyaan sikap, yaitu suatu pernyataan mengenai objek sikap

b. Analisa kuantitatif. Untuk analisa ini menggunakan statistik yaitu dengan mengguankan Regresi linier sederhana. Menurut Tika (2006), analisis korelasi sederhana ini dilakukan bila hubungan dua variabel berupa hubungan kausah atau fungsional.

\section{ANALISA DAN PEMBAHASAN ANALISA HASIL PENELITIAN UJI VALIDITAS}

Berikut hasil perhitungan uji validitas dari 12 item pertanyaan dalam penelitian ini. Hasil uji validitas tersebut akan dipaparkan dibawah ini :

\section{Faktor strategis dengan item :}

a. Perlakuan karyawan pada saat menyambut kedatangan pelanggan atau pada saat menerima telpon dari pelanggan $r x y=0,396>0,312$

b. Perlakuan karyawan pada saat pelanggan berkonsultasi rxy $=0,351>0,312$

\section{Faktor operasional dengan item :}

a. Menginformasikan melalui SMS rxy $=0,305<0,312$

b. Menginformasikan iklan memalui mediat TV rxy $=0,558>0,312$

3. Faktor Analitis dengan item :

a. Memberikan solusi sesuai informasi yang diberikan pelanggan $r x y=0,537>0,312$

b. Menyediakan bermacam-macam pake data exy $=0,528>0,312$

c. Menyediakan XL-center rxy $=0,580>0,312$

4. Faktor tingkat loyalitas pelanggan dengan item :

a. Kepuasan dengan kebutuhan berkomunikasi menggunakan $X L$ rxy $=0,671>0,312$

b. Kepuasan dengan informasi yang diberikan $X L$ rxy $=0,769>0,312$

c. Mudah dalam mengevaluasi pilihan fitur paket $\mathrm{XL}$ rxy $=0,628>0,312$ 
ISSN $1412-2936$

EISSN 2549-7308

d. Mudah dalam memutuskan membeli fitur paket $\mathrm{XL}$ rxy $=0.554>0,312$

e. Respon baik setelah melakukan pembelian fitur paket $X L r x y=0,539>0,312$

\section{UJI REABILITAS}

Diketahui hasil $r$ hitung dari variabel $X=0,408$ dan $r$ hitung dari variabel $Y=0,627$ maka dengan membandingkan nilai $r$ tabel $0,05=0,312$ ternyata $r$ hitung $>$ dari pada $r$ tabel. Maka instrumen data pada penelitian ini baik variabel $X$ dan $Y$ adalah Reabel.

\section{HASIL PERSAMAAN LINIER REGRESI SEDERHANA}

Koefesien diperoleh menggunakan bantuan program SPSS 16 for windows dengan data yang telah diperoleh kemudian di input dan diolah ke dalam progaram SPSS 16 for windows. Untuk hasilnya ada pada tabel dibawah ini :

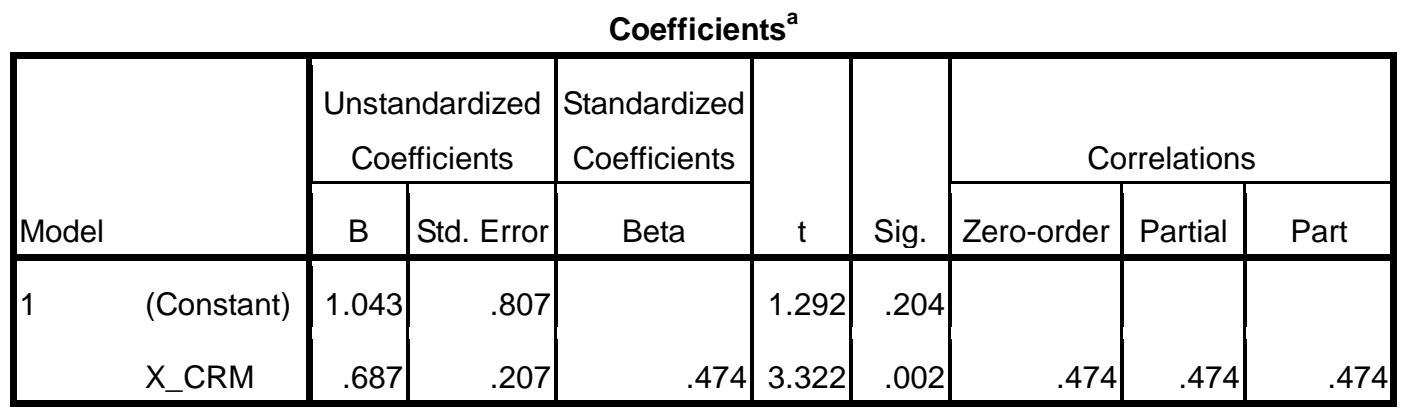

a. Dependent Variable: Y_Loyalitas

\section{HASIL REGRESI PEARSON CORRELATION}

Hasil regresi pearson correlation menggunakan bantuan program SPSS 16 for windows dan dari data yang telah disajikan di input dan diolah kedalam program SPSS 16 for windows. Untuk hasilnya ada pada tabel dibawah ini :

\begin{tabular}{|ll|r|r|}
\hline \multicolumn{1}{|c|}{ Correlations } & \multicolumn{1}{c|}{} \\
\hline Pearson Correlation & Y_Loyalitas & X_CRM \\
& Y_Loyalitas & 1.000 & .474 \\
& X_CRM & .474 & 1.000 \\
\hline Sig. (1-tailed) & Y_Loyalitas &. & .001 \\
& X_CRM & .001 & \\
\hline N & Y_Loyalitas & 40 & 40 \\
& X_CRM & 40 & 40 \\
\hline
\end{tabular}

PEMBAHASAN

ANALISA KUALITATIF
Secara kualitatif dari hasil jawaban 40 Responden dapat disusun sebagai berikut : 
ISSN 1412-2936

EISSN 2549-7308

a. Loyalitas pelanggan kategori cukup $47,5 \%$

b. Faktor strategis kategori baik $70 \%$

c. Faktor oprasional kategori baik $42,5 \%$

d. Faktor analitis kategori baik $45 \%$

\section{ANALISA KUANTITATIF}

$Y=1,043+0,687 X$

- Konstanta sebesar 1,043. Artinya jika CRM sama dengan nol maka loyalitas pelanggan sebesar 1.034 atau $104,3 \%$.

- Faktor CRM 0,687. Artinya jika CRM ditingkatakan satu-satuan maka menaikkan loyalitas pelanggan sebesar 0,687 atau $68,7 \%$

Sehingga loyalitas pelanggan cenderung positif sebesar $104,3 \%$ dengan faktor CRM sebesasr $68,7 \%$

\section{ANALISA KORELASI}

Hasil perhitungan $R$ dan $R$ square menggunakan bantuan program SPSS 16 for windows dan dari data yang telah disajikan di input dan diolah kedalam program SPSS 16 for windows. Hasil perhitungan $\mathrm{R}$ dan $\mathrm{R}$ Square pada tabel di atas yaitu memberikan informasi tentang hubungan atau korelasi antara variabel bebas yatiu CRM dan variabel terikat yaitu loyalitas pelayanan yang dimediasi oleh kepuasan pelanggan. Nilai $R$ atau muliper $R$ sebesar $47,4 \%$ yaitu menggambarkan hubungan antara variabel bebas bersifat sedang. Sedangkan nilai $R$ Square atau derteriman $\mathrm{R}$ sebesar $22,5 \%$ artinya $(100,0 \%-22,5 \%)=77,5 \%$ di pengaruhi oleh faktor lain yang tidak diteliti dalam penelitian ini.

\section{UJI HIPOTESIS}

Uji $t$ atau $t$ tes adalah bertujuan untuk menguji signifikasi variabel dependen terhadap variabel independen. Untuk membuktikan kebenaran dari hipotesis yang ada dalam penelitian ini maka perlu dibuktikan dengan melakukan uji hipotesis yaitu dengan menggunakana uji $t$ atu $t$ tes. Berdasarkan hasil perhitungan diperoleh t hitung untuk variabel CRM $(X)$ yang terdiri dari strategis, operasional dan analitis sebesar 3,322 dan kalau di konsultasikan dengan tabel $t$ sebesar 2,021 sehingga t hitung $>t$ tabel maka di ambil kesimpulan bahwa dugaan variabel CRM bepengaruh secara signifikan terhadap loyalitas pelanggan yang $\mathrm{XL}$ Axiata terbukti kebenarannya, hal ini dapat dilihat dari $t$ hitung $>t$ tabel. Selanjutnya dihitung dengan $t$ tabel dengan taraf kesalahan $5 \%$ dan dari $t$ hitung diperoleh 0,02.

Apabila $\alpha \leq 0,05$ maka $\mathrm{Ho}$ ditolak atau $\mathrm{Ha}$ diterima dan apabila $\alpha \geq 0,05$ maka Ho diterima atau $\mathrm{Ha}$ ditolak. Apabila dikonsultasikan $0,02<0,05$ dapat diambil kesimpulan bahwa $\mathrm{Ho}$ ditolak dan $\mathrm{Ha}$ diterima.

\section{KESIMPULAN DAN SARAN}

Penelitian ini mengkaji tentang pengaruh CRM terhadap loyalitas pelanggan XL Axiata Sampang, yaitu :

1. CRM terdiri dari strategis, analitis dan oprasional merupakan suatu proses suatu perusahaan dalam menciptakan kepuasa pelanggan dengan menjalin hubungan jangka panjang yang akan mendatangkan loyalitas pelanggan. Dalam penelitian ini diketahui bahwa variabel-variabel CRM berpengaruh terhadap loyalitas pelanggan yang dimediasi kepuasan 
ISSN 1412-2936

EISSN 2549-7308

pelanggan $\mathrm{XL}$ Axiata Sampang dengan thitung 3,322 dan kalau di konsultasikan dengan tabel $t$ sebesar 2,021 sehingga $t$ hitung $>t$ tabel maka di ambil kesimpulan bahwa dugaan variabel CRM bepengaruh secara signifikan terhadap loyalitas pelanggan $\mathrm{XL}$ Axiata terbukti kebenarannya. Selanjutnya dihitung dengan $t$ tabel dengan taraf kesalah $5 \%(0,05)$ dan dari t hitung diperoleh 0,02 . Apabila $\alpha \leq 0,05$ maka $\mathrm{Ho}$ ditolak atau Ha diterima dan apabila $\alpha$ $\geq 0,05$ maka $\mathrm{Ho}$ diterima atau $\mathrm{Ha}$ ditolak. Apabila dikonsultasikan $0,02<0,05$ dapat diambil kesimpulan bahwa Ho ditolak dan Ha diterima.

2. Hasil perhitungan $R$ dan $R$ Square pada tabel di atas yaitu memberikan informasi tentang hubungan atau korelasi antara variabel bebas yatiu CRM dan variabel terikat yaitu loyalitas pelanggan. Nilai $R$ atau muliper $R$ sebesar 0,474 atau $47,4 \%$ yaitu menggambarkan hubungan antara variabel bebas bersifat sedang. Sedangkan nilai $R$ Square atau derteriman $R$ sebesar 0,225 atau $22,5 \%$ artinya $(100,0 \%-22,5 \%)=$ $77,5 \%$ di pengaruhi oleh faktor lain yang tidak diteliti dalam penelitian ini.

Dalam upaya menciptakan loyalitas pelanggan, maka sebaiknya XL Axiata memperhatikan hal-hal berikut :

a. Berdasarkan penelitian tentang CRM terhadap loyalitas pelanggan sebiaknya XL lebih aktif menelusuri keinginan pelanggan baik dari paket yang ditawarkan, atau SMS yang dikirimkan tentang informasi yang penting saja, karena terlalu banyak SMS membuat pelanggan menggerutu bahkan tidak membacanya, hal itu disebabkan informasi yang tidak begitu penting.

b. Penelitian ini perlu dikembangkan lebih lanjut dengan penelitian sejenis dengan lokasi yang berbeda atau dengan menggunkan variabel lain agar hasil penelitian secara umum dapat bermanfaat untuk perusahaan dalam menjaga hubungan pelanggan menuju loyalitas.

\section{DAFTAR PUSTAKA}

Arikunto, Suharsimi. 2010. Prosedur Penelitian Suatu Pendekatan Praktik. Rineka Cipta : Jakarta.

Azwar, Saifuddin. 2011. Metode penelitian. Pustaka Pelajar Offset : Yogyakarta.

Body, Assion Lawson and Limayem, Moez. 2006. The impact of customer relationship management on customer royalty: the moderating role of web site characteristics. Jurnal ilmiah

Bungin, M. Burhan. 2006. Metodologi Penelitian Kuantitaf: Komunikasi, Ekonomi, dan Kebijakan Publik serta IImu-IImu Sosial lainnya. Kencana : Jakarta

Buttle, Francis. 2007. Customer Relationship Management. Bayu Media Publishing : Malang

Griffin, Jill. 2003. Customer loyalty: menumbuhkan dan mempertahankan kestiaan pelanggan. PT. Gelora Aksara Pratama : Jakarta

Hesti Kartika Sari. 2009. Efektivitas Loyality Program dalam CRM Terhadap Kepuasan dan Loyalitas Pelanggan 
ISSN 1412-2936

EISSN 2549-7308

(Studi Program Im3@school Community pada PT. Indosat, Tbk Cabang Malang). Jurnal IImu Komunikasi Vol. 6 No. 2 Des 2009 Hal : 177-206

Kotler dan Amstrong. 2006. Principles of Marketing Eleven Edition. Pearson Educaion Inc : New Jersey

Narbuko, Cholid dan Achmadi, Abu. 2013. Metodologi penelitian. PT. Bumi Aksara : Jakarta.

Noor, Juliansyah. 2011. Metodologi penelitian. Kecana : Jakarta.

Rinny E. Kalalo. 2013. CRM dan Kualitas Pelayanan Pengaruhnya Terhadap Loyalitas Konsumen PT. Matahari Dept. Store Manado. ISSN : 2303-1174. Jurnal
EMBA Vol. 1 No. 14 Des 2013 Hal : 1553-1561

Satriyo UP Bhaskara dkk. 2014. CRM dan Personal Selling Pengaruhnya Terhadap Kepuasan Konsumen Pada PT. Virgo Ekspres Tours \& Travel Manado. ISSN : 2303-1174. Jurnal EMBA Vol. 2 No. 1 Maret $2014 \mathrm{Hal}: 99-110$

Sugiyono. 2010. Metode penelitian Kuantitatif, Kualitatif dan $R \& D$. ALFABETA : Bandung

Tika, Moh. Pabundu. 2006. Metodolgi Riset Bisnis. PT. Bumi Aksara : Jakarta 